
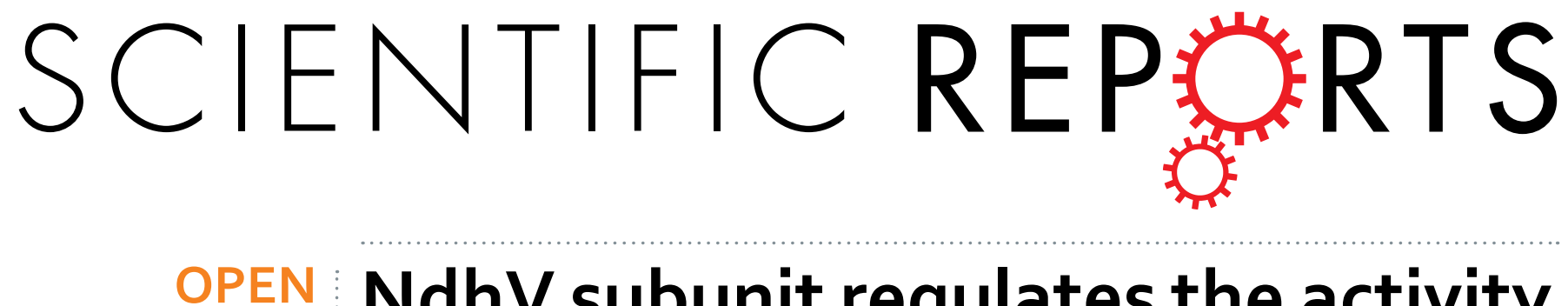

\title{
NdhV subunit regulates the activity of type-1 NAD(P)H dehydrogenase under high light conditions in cyanobacterium Synechocystis sp. PCC 6803
}

\begin{abstract}
Xin Chen ${ }^{1,2}$, Zhihui He${ }^{1}$, Min Xu ${ }^{1}$, Lianwei Peng ${ }^{3}$ \& Hualing $\mathrm{Mi}^{1}$
The cyanobacterial NAD(P)H dehydrogenase (NDH-1) complexes play crucial roles in variety of bioenergetic reactions. However, the regulative mechanism of $\mathrm{NDH}-1$ under stressed conditions is still unclear. In this study, we detected that the NDH-1 activity is partially impaired, but the accumulation of NDH-1 complexes was little affected in the $N d h V$ deleted mutant ( $\Delta n d h V)$ at low light in cyanobacterium Synechocystis sp. PCC 6803. $\Delta$ ndhV grew normally at low light but slowly at high light under inorganic carbon limitation conditions (low $\mathrm{pH}$ or low $\mathrm{CO}_{2}$ ), meanwhile the activity of $\mathrm{CO}_{2}$ uptake was evidently lowered than wild type even at $\mathrm{pH}$ 8.0. The accumulation of $\mathrm{NdhV}$ in thylakoids strictly relies on the presence of the hydrophilic subcomplex of NDH-1. Furthermore, NdhV was co-located with hydrophilic subunits of NDH-1 loosely associated with the NDH-1L, NDH-1MS' and NDH-1M complexes. The level of the NdhV was significantly increased at high light and deletion of NdhV suppressed the up-regulation of $\mathrm{NDH}-1$ activity, causing the lowered the photosynthetic oxygen evolution at pH 6.5 and high light. These data indicate that $\mathrm{NdhV}$ is an intrinsic subunit of hydrophilic subcomplex of NDH-1, required for efficient operation of cyclic electron transport around photosystem I and $\mathrm{CO}_{2}$ uptake at high lights.
\end{abstract}

Type-1 NAD(P)H dehydrogenase (NDH-1) complexes function in a variety of bioenergetic reactions, including respiration, cyclic electron transport around photosystem I (PSI) ${ }^{1}$ and $\mathrm{CO}_{2}$ uptake ${ }^{2}$ in cyanobacteria. The subunits of NDH-1 show a high homology with those in chloroplast NDH. Chloroplast NDH consists of more than 28 subunits, among those, NdhA-NdhK are plastid-encoded and others are nuclear-encoded ${ }^{3}$ and cyanobacterial NDH-1 consists of 17 subunits at least. Structurally, the chloroplast NDH is more complicate compared with the cyanobacterial NDH-1. According to the structural model of chloroplast NDH proposed by Ifuku et al. ${ }^{3}$, in addition to the L-shape structure consisting of subcomplex A, donor binding domain and membrane subcomplex similar with that of cyanobacterial NDH-1, the chloroplast NDH contains a subcomplex B which forms a second hydrophilic arm that extends to the stroma and attaches to the membrane subcomplex with two transmembrane proteins, PnsB4 ${ }^{4}$ and $\mathrm{PnsB}^{5}$, and the lumen subcomplex L, which consists of PnsL1-PnsL5 (photosynthetic NDH subunit of lumenal location). However, three subunits of Complex I (NuoE, NuoF, and NuoG) involved in accepting electrons from NADH in Escherichia coli are missing from cyanobacterial and chloroplast $\mathrm{NDH}^{6}$. There are six NdhD and three NdhF genes in Synechocystis sp. PCC 6803 (hereafter Synechocystis 6803) (CyanoBase, the genome database for cyanobacteria), which form different NDH-1 complexes involved in diverse physiological functions. Proteomic analysis of cyanobacterial NDH-1 complexes has revealed the presence of three complexes NDH-1L (large size), NDH-1M (medium size) and NDH-1S (small size) in Synechosystis 68037. Further research suggested that NDH-1L functions in cyclic electron transport and respiration and NDH-1M and NDH- $1 \mathrm{~S}_{\text {in }} \mathrm{CO}_{2}$

${ }^{1}$ National Key Laboratory of Plant Molecular Genetics, Institute of Plant Physiology and Ecology, Shanghai Institutes for Biological Sciences, Chinese Academy of Science, 300 Fenglin Road, Shanghai 200032, China. ${ }^{2}$ University of Chinese Academy of Sciences, Beijing 100049, China. ${ }^{3}$ Key Laboratory of Photobiology, Institute of Botany, Chinese Academy of Sciences, Beijing 100093, China. Correspondence and requests for materials should be addressed to H.M. (email: hlmi@sibs.ac.cn) 
uptake ${ }^{8}$. In contrast to the crystal structure of Complex $\mathrm{I}^{9}$, NDH-1 from cyanobacteria is speculated to possess an oxygenic photosynthesis-specific (OPS) domain ${ }^{10}$ comprised of NdhL-NdhO identified in Synechocystis $6803^{11,12}$. Several NDH subunits function in stabilization of NDH-1. NdhP and NdhQ were found in the purified NDH-1L complex from T. elongatus ${ }^{13}$. NdhP is involved in the respiratory and cyclic electron flow ${ }^{14}$ and stabilization of the NDH-1L complex ${ }^{15}$. NdhQ is also essential for stabilization of the large complex of NDH- $1^{16}$. NdhS participates in the activity of cyclic electron flow around PSI in Arabidopsis ${ }^{17}$ or in cyanobacteria ${ }^{18}$, and serves as the Fd docking site domain, accepting electrons from Fd in chloroplasts ${ }^{19}$. Furthermore, He et al. ${ }^{20}$ have found that the NDH-1L complex interacts with Fd via the subunit NdhS in Thermosynechococcus elongatus.

Cyanobacteria utilize both $\mathrm{CO}_{2}$ and $\mathrm{HCO}_{3}{ }^{-}$as carbon species ${ }^{21}$. The dissolved inorganic carbon is $\mathrm{pH}$-dependent. With increasing $\mathrm{pH}$, the ratio of $\mathrm{HCO}_{3}{ }^{-}$to $\mathrm{CO}_{2}$ continues to rise ${ }^{22}$. In contrast, the water with acid $\mathrm{pH}$ is favorable for providing a sufficient $\mathrm{CO}_{2}$ supply. Cyanobacteria possess a $\mathrm{CO}_{2}$-concentrating mechanism (CCM) that enables to raise the concentration of inorganic carbon $\left(\mathrm{Ci}, \mathrm{HCO}_{3}{ }^{-}\right.$and $\left.\mathrm{CO}_{2}\right)$ at the carboxylation site to a high level for efficient $\mathrm{CO}_{2}$ fixation despite the low affinity of their Rubisco for $\mathrm{CO}_{2}^{23,24}$. To date, five inorganic transporters have been found including two $\mathrm{Na}^{+}$-dependent $\mathrm{HCO}_{3}{ }^{-}$transporters (BicA and SbtA), one ATPase-dependent $\mathrm{HCO}_{3}{ }^{-}$transporter (BCT1), and two $\mathrm{CO}_{2}$-uptake $\mathrm{NDH}-1$ complexes in Synechocystis 6803 and other cyanobacterial strains ${ }^{24-26}$. As one of $\mathrm{CO}_{2}$ uptake systems, NDH-1MS complex, consisting of NdhD3, NdhF3 and CupA (ChyY), is inducible at limiting Ci conditions and has a higher uptake affinity for $\mathrm{CO}_{2}{ }^{27-29}$. Further research showed that the proteins encoded by $N d h F 3 / N d h D 3 / C u p A / C u p S$ formed a small complex NDH-1S, in which CupA and a small protein CupS were identified as subunits of cyanobacterial NDH-1 by proteomic analysis ${ }^{30,31}$. NDH-1S and NDH-1M form an NDH-1MS complex which has been isolated from a Thermosynechococcus elongatus strain in which the $\mathrm{C}$ terminus of NdhL has been tagged with 6-His. This complex is easily dissociated into NDH-1M and NDH-1S complexes ${ }^{31}$. As a homologous gene of cupA, cupB (chyX) is involved in constitutive $\mathrm{CO}_{2}$ uptake system encoded by $N d h D 4 / N d h F 4 / C u p B$ which formed a small complex $\mathrm{NDH}-1 \mathrm{~S}^{\prime 28,29}$. Based on the purification of a $450 \mathrm{kDa}$ complex contained both $\mathrm{NdhH}$ and CupB protein, it has been suggested that the complex is NDH-1MS' located in the thylakoid membranes ${ }^{32}$.

Previous studies have shown that the cyclic electron flow around PS I mediated by NDH functions in protection against stressed conditions. Ogawa ${ }^{2}$ has found that deletion of $N d h B$ gene resulted in the unable survival phenotype of Synechocystis 6803 under low $\mathrm{CO}_{2}$ (air) condition, suggesting that the NDH-1 functions in inorganic carbon transport. The activity of cyclic electron flow around PSI mediated by NDH-1 has been found to be enhanced under stressed conditions, including low $\mathrm{CO}_{2}{ }^{33}$, strong light ${ }^{34}$. However, how NDH-1 participates in the regulation of photosynthesis is still unclear.

Recently, NdhV is reported to function in stabilization of chloroplast NDH-like complex in Arabidopsis ${ }^{35}$ and heat tolerance in Synechocystis $6803^{36}$. However, the mechanism of $\mathrm{NdhV}$ in response to stressed conditions is not clear. Here we report that cyanobacterial NdhV localizes in the hydrophilic subcomplex of NDH-1MS', NDH-1L and NDH-1M. Further analysis showed that NdhV functions in regulation of NDH-1 activity for efficient operation of cyclic electron flow around PS I and $\mathrm{CO}_{2}$ uptake in Synechocystis 6803 in response to high lights.

\section{Results}

Deletion of $N d h V$ partially arrests NDH-1 activity. To reveal the function of $N d h V$ in cyanobacteria, we inactivated the cyanobacterial $\mathrm{NdhV}$ protein by inserting a kanamycin resistance $\left(\mathrm{kan}^{R}\right)$ cassette into its coding region (Fig. 1A). The PCR analysis of the $N d h V$ locus using the $n d h V$-up-F and $n d h V$-Dn-R primers showed a band of $1.5 \mathrm{Kbp}$ in the WT and $2.7 \mathrm{Kbp}$ in the $\Delta n d h V$ mutant which contained an extra Kanamycin resistance cassette of about $1.2 \mathrm{Kbp}$; it confirmed the complete segregation of the $\Delta n d h V$ allele in this mutant (Fig. 1B).

Post-illumination increase in Chl fluorescence was explained as the reduction of plastoquinone (PQ) by the electrons from photoreductants accumulated in the stroma or cytosol during illumination, which reflects cyclic electron transport around PSI mediated by NDH-1 ${ }^{37,38}$ in cyanobacteria and by chloroplast $\mathrm{NDH}$ in higher plant $^{39}$. By comparison with WT, the post-illumination increase in Chl fluorescence was partly impaired in two lines of $n d h V$ deleted mutants $\Delta n d h V-1$ and $\Delta n d h V-2$ (Fig. 1C), suggesting that NdhV contributes to the NDH-1 activity.

Growth of $\Delta$ ndh $V$ was suppressed under high light and low $\mathrm{pH}$ conditions. In addition to cyclic electron flow around PSI, NDH-1 is also involved in $\mathrm{CO}_{2}$ uptake ${ }^{2}$. To examine whether $\mathrm{NdhV}$ participates in $\mathrm{CO}_{2}$ uptake, we compared the growth phenotype between WT and $\Delta n d h V$ under various conditions, low $(40 \mu \mathrm{mol}$ photons $\mathrm{m}^{-2} \mathrm{~s}^{-1}$ ) or high light $\left(300 \mu \mathrm{mol}\right.$ photons $\mathrm{m}^{-2} \mathrm{~s}^{-1}$ ), low (below $\mathrm{pH} 7.5$ ), or high $\mathrm{pH}$ (above $\mathrm{pH}$ 7.5), high (2\%) or low $\mathrm{CO}_{2}(0.04 \%)$. With the $\mathrm{pH}$ increasing to higher than 7.0, the concentration of $\mathrm{HCO}_{3}{ }^{-}$is predominant but that of $\mathrm{CO}_{2}$ becomes minor, while at the low pH below 6.5 condition, the concentration of $\mathrm{HCO}_{3}{ }^{-}$becomes minor and that of $\mathrm{CO}_{2}$ is predominant. The growth phenotype was almost the same under $\mathrm{pH} 8.0$ either at low light or high light (Fig. 2A-D). The growth of $\Delta n d h V$ was slightly slow at low pH, low light, low $\mathrm{CO}_{2}$ (Fig. 2B) or high light, high $\mathrm{CO}_{2}$ (Fig. 2C) and more evidently under high light, low $\mathrm{CO}_{2}$ (Fig. 2D). To confirm the difference, we further compared the growth rate in the liquid culture conditions bubbling with $2 \% \mathrm{CO}_{2}$ at $\mathrm{pH} 6.5$ at low light or high light. The growth rate was identical between $\Delta n d h V$ and wild type under low light condition in liquid (Fig. 2E), consistent with the results on agar (Fig. 2A). However, the growth of $\Delta n d h V$ was slower than WT under the high light condition (Fig. 2F), suggesting that NdhV plays an important role under the stressed conditions. In contract, the $n d h B$ defective mutant (M55) in which both the PSI-cyclic electron flow and $\mathrm{CO}_{2}$ uptake were inactivated, could hardly grow up at $\mathrm{pH} 6.5$ under either low light or high light conditions (Fig. 2E,F), similar to the observation by Ogawa (1991). 
A

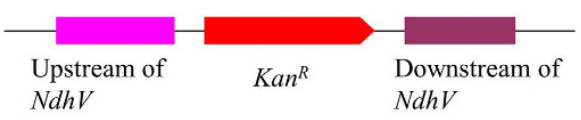

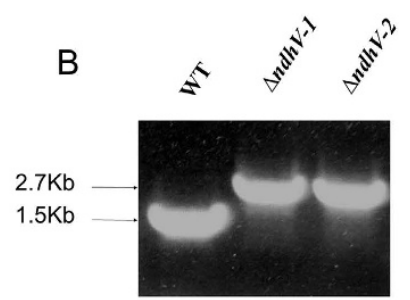

C

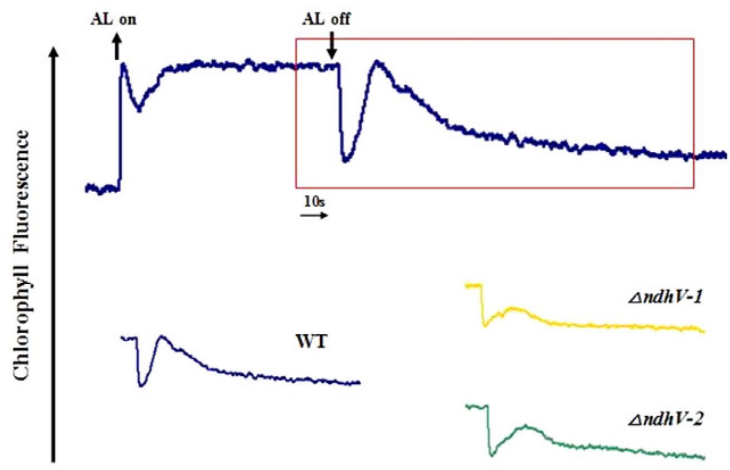

Figure 1. NdhV gene deletion and its effect on NDH-1 activity. (A) Construction of plasmid to generate $N d h V$ deleted mutant $(\Delta n d h V)$. Schematic representation of the $\Delta n d h V$ mutant locus. A kanamycin resistance cassette about $1.2 \mathrm{~Kb}$ was inserted into the $N d h V$ gene. (B) PCR segregation analysis of the $\Delta n d h V$ mutant using the $n d h V$-up-F and $n d h V$-Dn-R primers (Table S1). (C) Monitoring of NDH-1 activity using chlorophyll fluorescence analysis. The top curve shows a typical trace of chlorophyll fluorescence in the WT of Synechocystis 6803. The cells $\left(\mathrm{OD}_{730}\right.$ around 0.4$)$ supplemented with $10 \mathrm{mM} \mathrm{NaHCO}_{3}$ were used for the measurement. After the sample was exposed to the actinic light (AL, $100 \mu \mathrm{mol}$ photons $\mathrm{m}^{-2} \mathrm{~s}^{-1}$ ) for $90 \mathrm{~s}$, AL was turned off, and the transient increase in chlorophyll fluorescence level was recorded, which was used to ascribe NDH-1 activity. The inset shows magnified traces from the box area.

Suppression of the activity of $\mathrm{CO}_{2}$ uptake in $\Delta n d h V$. To confirm whether the $\mathrm{CO}_{2}$ uptake activity was affected by deletion of $\mathrm{NdhV}$, we compared the rate of $\mathrm{CO}_{2}$ uptake in $\mathrm{WT}, \Delta n d h V$, and M55 in which only $\mathrm{NDH}-1 \mathrm{~S}$ is active in the $\mathrm{CO}_{2}$ acquisitive systems, using a portable open-flow gas exchange system under high lights and high or low $\mathrm{CO}_{2}$ conditions. Cell suspensions were placed on the BG-11 agar plate to measure the $\mathrm{CO}_{2}$ uptake rate. The rate of $\mathrm{CO}_{2}$ uptake was lowered by about $10 \%$ in $\Delta n d h V$ than that in WT at $100 \mu$ mol photons $\mathrm{m}^{-2} \mathrm{~s}^{-1}$ either under high $\mathrm{CO}_{2}$ or low $\mathrm{CO}_{2}$ conditions (Fig. $3 \mathrm{~A}$ ), and at $300 \mu$ mol photons $\mathrm{m}^{-2} \mathrm{~s}^{-1}$ under low $\mathrm{CO}_{2}$, but not under high $\mathrm{CO}_{2}$ condition (Fig. 3B). In contrast, the rate of $\mathrm{CO}_{2}$ uptake was almost completely suppressed in $\mathrm{M} 55$ (Fig. 3A,B) suggesting the loss of function of both NDH-1MS and NDH-1MS' in the mutant. These results demonstrated that deletion of $\mathrm{NdhV}$ suppresses the $\mathrm{CO}_{2}$ uptake activity under high lights and $\mathrm{CO}_{2}$ limitation conditions.

The proton gradient across thylakoid membranes was lowered in $\Delta n d h V . \quad$ It has been suggested that cyanobacterial NDH-1 provides ATP for $\mathrm{CO}_{2}$ uptake ${ }^{2}$. To investigate whether NdhV is involved in this process, the proton gradient across thylakoid membranes, which drives ATPase to synthesis ATP was compared between WT and $\Delta n d h V$. Quinacrine (QA) fluorescence quenching can be used for the determination of $\Delta \mathrm{pH}$ across the thylakoid membrane for intact cells of Synechocystis $6803^{40}$. The QA fluorescence quenching was decreased by about $20 \%$ in $\Delta n d h V$ mutants and $40 \%$ in M55 compared with those in WT (Fig. 3C), suggesting that $\mathrm{NdhV}$ is involved in regulation of proton gradient across thylakoid membrane.

NdhV localizes to the thylakoid membrane and its accumulation relies on the electron donor domain of NDH-1M of NDH-1MS', NDH-1L. The previous study demonstrated that Arabidopsis NdhV is mainly localized to the thylakoid membrane $e^{35,36}$. As a homologous protein, the localization of the cyanobacterial NdhV was investigated with a polyclonal antibody against the recombinant cyanobacterial NdhV. Western blotting analysis detected a band with a molecular mass of about $15 \mathrm{kDa}$ (the theoretical molecular mass of mature $\mathrm{NdhV}$ is $\sim 18 \mathrm{kDa}$ ) in the thylakoid and also in the stromal fractions of WT, but absent in those of $\Delta n d h V$ (Fig. 4A), confirming that the cyanobacterial NdhV is mainly localized to the thylakoid membrane.

In cyanobacteria, a total of $4 \mathrm{NdhD}$ isoforms are present and they are located in different $\mathrm{NDH}-1$ complexes. Given that NDH-1L, NDH-1MS, NDH-1MS' were respectively defective in $\Delta n d h D 1 / D 2, \Delta n d h D 3$ and $\Delta n d h D 4$ mutant in Synechocystis $6803^{30}$, suggesting that NDH-1M is stable in those NdhD deleted mutants, we checked the amount of NdhV in different NdhD deleted mutants. As shown in Fig. 4B, there was no much difference in the amount of $\mathrm{NdhV}$ among WT and the various $N d h D$ deleted mutants, suggesting that $\mathrm{NdhV}$ is present in NDH-1M complex. 
A
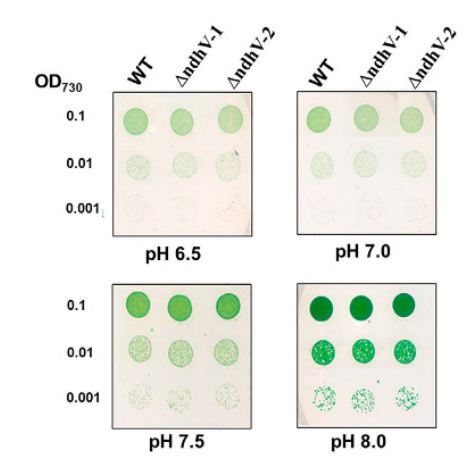

B

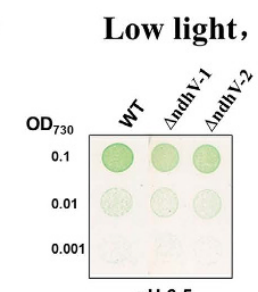

$\mathrm{pH} 6.5$
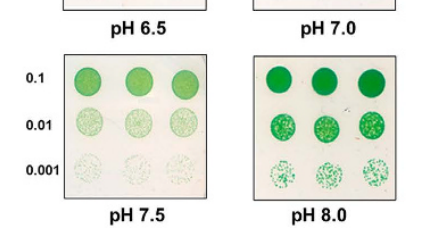

C High light, high $\mathrm{CO}_{2}$
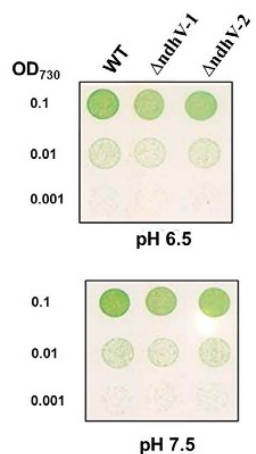

pH 7.5
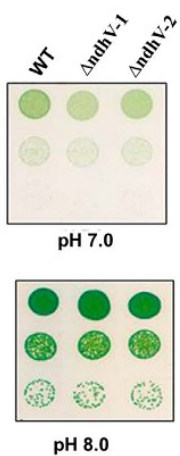

pH 8.0
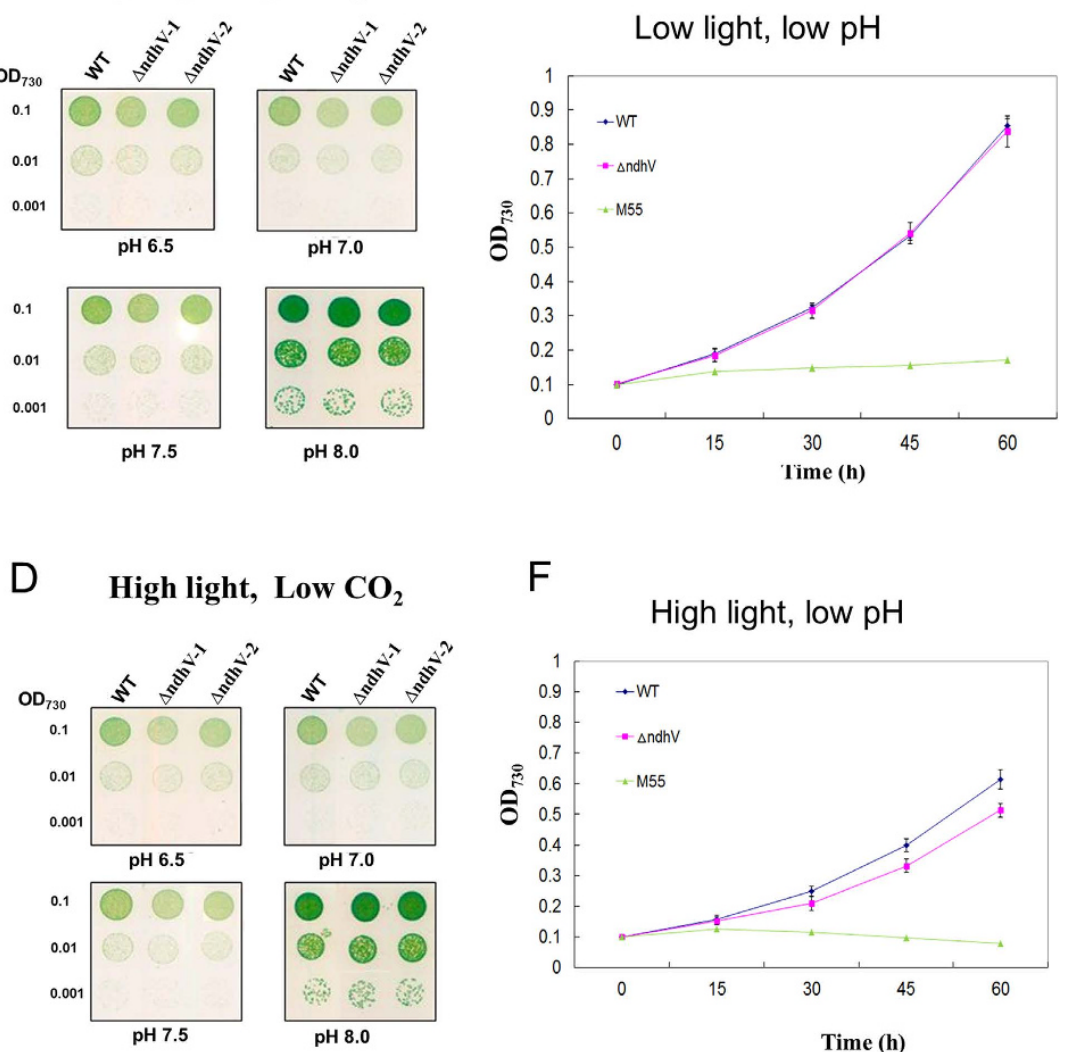

$\mathrm{F}$

High light, low pH

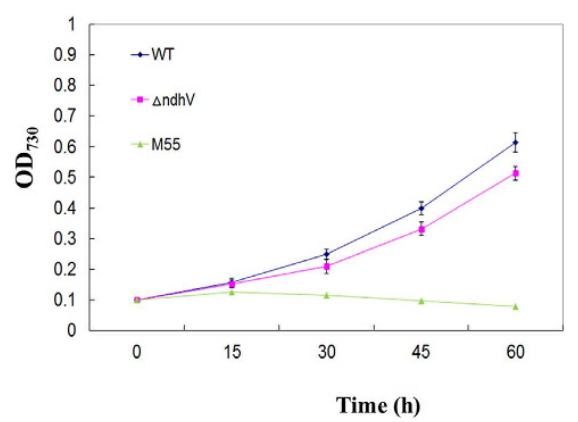

Figure 2. The growth phenotype of WT and $\Delta n d h V$ strains. (A-D) Five microliters of the cell suspensions with the $\mathrm{OD}_{730} \mathrm{~nm}$ values of $0.1,0.01$, and 0.001 were spotted on agar plates containing BG11 buffer at different $\mathrm{pHs}$ and grown at a low light $\left(40 \mu \mathrm{mol}\right.$ photons $\left.\mathrm{m}^{-2} \mathrm{~s}^{-1}\right)$, high $\mathrm{CO}_{2}(3 \% \mathrm{v} / \mathrm{v})(\mathrm{A})$; low light, low $\mathrm{CO}_{2}(0.04 \% \mathrm{v} / \mathrm{v})$ (B); high light $\left(300 \mu \mathrm{mol}\right.$ photons $\left.\mathrm{m}^{-2} \mathrm{~s}^{-1}\right)$ and high $\mathrm{CO}_{2}(\mathbf{C})$; ligh light and low $\mathrm{CO}_{2}(\mathbf{D})$ for five days.

(E,F) Cell density of WT, $\Delta n d h V$, and M55 strains were measured at different times after grown at low light $\left(40 \mu \mathrm{mol}\right.$ photons $\left.\mathrm{m}^{-2} \mathrm{~s}^{-1}\right)$ and low $\mathrm{pH}(\mathrm{pH} 6.5)(\mathbf{E})$, or high light $\left(300 \mu \mathrm{mol}\right.$ photons $\left.\mathrm{m}^{-2} \mathrm{~s}^{-1}\right)$ and low $\mathrm{pH}$ $(\mathrm{pH} 6.5)(\mathbf{F}), 2 \% \mathrm{CO}_{2}(\mathrm{v} / \mathrm{v}$ in air). Values are means $\pm \operatorname{SD}(n=3)$. Values are means $\pm \operatorname{SD}(n=3)$.

To further confirm the association of NdhV with NDH-1M, the accumulation of NdhV in the mutants defective in different $\mathrm{Ndh}$ subunits was investigated by immunoblot. Figure $4 \mathrm{C}$ shows that $\mathrm{NdhV}$ was detected neither in $\mathrm{NdhB}$ defective mutant M55, in which both the NDH-1L and NDH-1M were disassembled ${ }^{30}$ nor in NdhM deleted mutant $\Delta n d h M$ in which all the NDH-1 complexes were disassembled ${ }^{41}$. The results indicate that the accumulation of NdhV relies on NDH-1M and the complexes containing NDH-1M, including NDH-1L, NDH-1MS and NDH-1MS'.

We further checked the accumulation of cyanobacterial NdhV in NdhS deleted mutant of Synechocystis 6803 $(\Delta n d h S)$. NdhV was hardly detected in $\Delta n d h S$ (Fig. 4C), consistent with the result obtained in Arabidopsis $n d h S /$ crr31 mutant (Fan et al. $)^{35}$ or in Synechocystis 6803 (Gao et al. $)^{36}$, suggesting that the stability of NdhV is dependent on the electron donor domain of NDH-1 in cyanobacteria. Furthermore, we checked the accumulation of $\mathrm{NdhV}$ in the mutant defective in the hydrophilic subunits of NDH-1. The amount of NdhV was reduced significantly in $N d h I$ partly deleted mutant $\left(\Delta n d h I_{U}\right)$ (Fig. $\left.4 \mathrm{C}\right)$. The result indicates that the accumulation of $\mathrm{NdhV}$ is dependent on the presence of the hydrophilic subcomplex of NDH-1related to its electron donor domain.

$\mathrm{NdhV}$ is loosely bound in NDH-1 complexes and its absence hardly affects the accumulation of other Ndh subunits and assembly of NDH-1 complexes under normal growth conditions. To investigate whether the accumulation of the NDH- 1 complexes is affected in $\Delta n d h V$, thylakoid protein complexes isolated from $\Delta n d h V$ and WT were separated by a 5-13\% gradient blue-native PAGE (BN-PAGE) followed by $2 \mathrm{D}$ SDS-PAGE for the immunoblotting analysis. The results show that in the wild type, NdhV presents as a free form and the bands corresponding to NDH-1L and NDH-1M complexes were detected using the antibody of NdhK, and the bands corresponding to NDH-1MS' and NDH-1 $\mathrm{S}^{\prime}$ complex could also be detected using the antibody of the key component CupB (Fig. 5A). However, in $\Delta n d h V$, these bands were almost the same as those in wild type, indicating that deletion of NdhV hardly affected the assembly of NDH-1 complexes, including NDH-1L, NDH-1MS' and NDH-1M (Fig. 5A), in accordance with the results in Arabidopsis that the NdhV is a protein easily dissociated from NDH-1 complexes during sample preparation and BN-gel electrophoresis. To overcome this limitation, we performed the chemical crosslinking experiments using the thylakoids isolated from WT. The result shows that NdhV co-migrates with the NdhI and NdhK subunits in the NDH-1M, NDH-1L, NDH-1MS' 

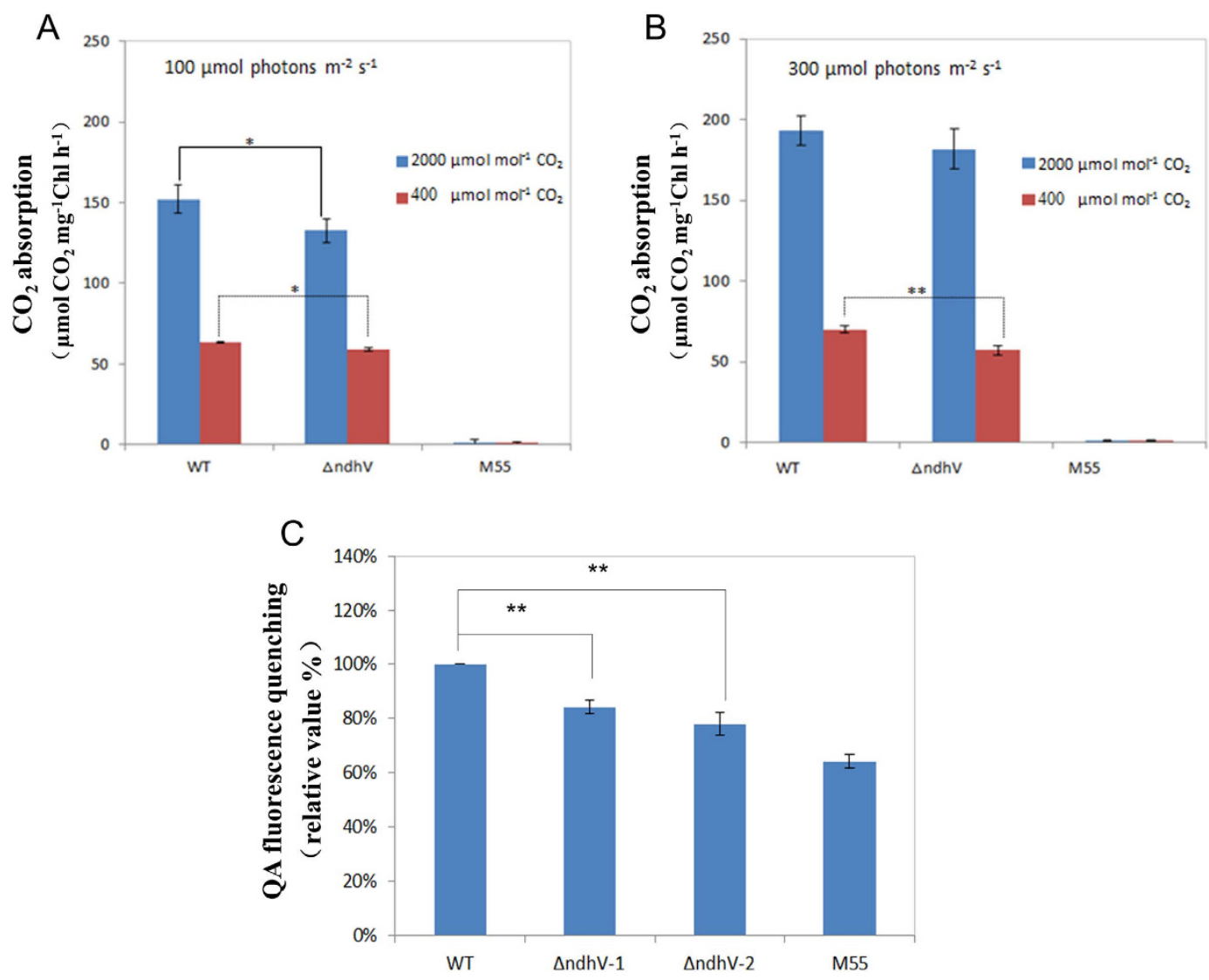

Figure 3. Comparison of the $\mathrm{CO}_{2}$ uptake and the proton gradient across thylakoid membranes between WT and $\Delta n d h V$ strains. $(\mathbf{A}, \mathbf{B})$ The rate of $\mathrm{CO}_{2}$ uptake in WT, $\Delta n d h V$ and $\mathrm{M} 55$ strains at $100 \mu$ mol photons $\mathrm{m}^{-2} \mathrm{~s}^{-1}(\mathbf{A})$ or at $300 \mu \mathrm{mol}$ photons $\mathrm{m}^{-2} \mathrm{~s}^{-1}(\mathbf{B})$. The cells of WT and mutant strains were harvested at midlogarithmic phase $\left(\mathrm{OD}_{730} \approx 0.5\right)$ and chlorophyll $a$ concentration was adjusted to $400 \mu \mathrm{g} \mathrm{ml}^{-1}$. $30 \mu \mathrm{l}$ of the cell suspensions were placed on the BG-11 agar plate. The activity of $\mathrm{CO}_{2}$ uptake was measured at $30^{\circ} \mathrm{C}$. The $\mathrm{CO}_{2}$ concentration was controlled at 400 or $2000 \mu \mathrm{mol} \mathrm{mol}^{-1}$. Values are means $\pm \mathrm{SE}$ of three independent measurements. Asterisk indicates significant differences ( $\mathrm{t}$-test, $* \mathrm{P}<0.05$ and $* * \mathrm{P}<0.01$ ). (C) Analysis of proton gradient across thylakoid membranes using QA (quinacrine) fluorescence quenching in $\mathrm{WT}, \Delta n d h V$ and M55 strains. Intact cells of WT and mutant strains were harvested at mid-logarithmic phase $\left(\mathrm{OD}_{730} \approx\right.$ $0.5)$ and then suspended at a final chlorophyll a concentration of $150 \mu \mathrm{g} \mathrm{ml}^{-1}$ in a reaction medium contained $5 \mathrm{mM}$ Tris/MES (pH 8.0), 0.3 M mannitol, $2 \mathrm{mM}$ DTT, $5 \mathrm{mM}$ D-Glucose, $1.5 \mathrm{mM}$ ATP, $5 \mu \mathrm{M}$ quinacridine. The quenching of QA fluorescence was induced by adding the cells sample to $2 \mathrm{ml}$ reaction mixture after the background fluorescence reached steady state about $2 \mathrm{~min}$ after started the measurement. The QA fluorescence quenching of WT is $5.02 \%$. Values are means $\pm \mathrm{SE}$ of three independent measurements. Asterisk indicates significant differences (t-test, $* \mathrm{P}<0.05$ and $* * \mathrm{P}<0.01$ ).

and a supercomplex around $1000 \mathrm{kDa}$, probably due to the aggregation of the NDH-1 (Fig. 5B). These results also confirm that $\mathrm{NdhV}$ is a subunit of cyanobacterial NDH-1 but easily dissociated from NDH-1 complexes. To know whether NdhV affects the accumulation of other subunits of NDH-1, we checked the amount of several subunits in different parts of cells from $\Delta n d h V$. The results show that there were no obvious difference of the amount of $\mathrm{NdhH}, \mathrm{I}, \mathrm{K}, \mathrm{M}$ either in total proteins, or in the supernatant or in the thylakoid membrane between the WT and $\Delta n d h V$ cultured at $\mathrm{pH} 6.5$ (Fig. 1SA) or at $\mathrm{pH} 8.0$ (Fig. 1SB).

The up-regulation of NDH-1 activity at high lights was suppressed in $\Delta n d h V$. Previous studies have indicated that NDH-1 activity was up-regulated by high light ${ }^{34}$. To test whether NdhV is required for up-regulation of NDH activity under high light conditions, we compared the NDH-1 activity under different light intensities between WT and $\Delta n d h V$. Figure 6A shows that the NDH-1 activity, reflected by the transient increase in Chl fluorescence after termination of actinic light, increased with the increase of the intensity of actinic light in WT, but the up-regulation of NDH-1 activity in response to high lights was significantly suppressed in $\Delta n d h V$. The results indicate that the up-regulation of NDH-1 activity is almost suppressed when NdhV is absent. Furthermore, we compared the changes of the amount of Ndh subunits after adaptation to the high light between WT and $\Delta n d h V$. As shown in Fig. 6B, after the growth light was shifted to the high light $(200 \mu \mathrm{mol}$ photons $\mathrm{m}^{-2} \mathrm{~s}^{-1}$ ) for $1 \mathrm{~h}$, the amounts of NdhH and NdhK were evidently increased by about 40\% and 35\%, respectively, both in WT and $\Delta n d h V$. Meanwhile, the amount of NdhV was approximately 2-fould higher at the 

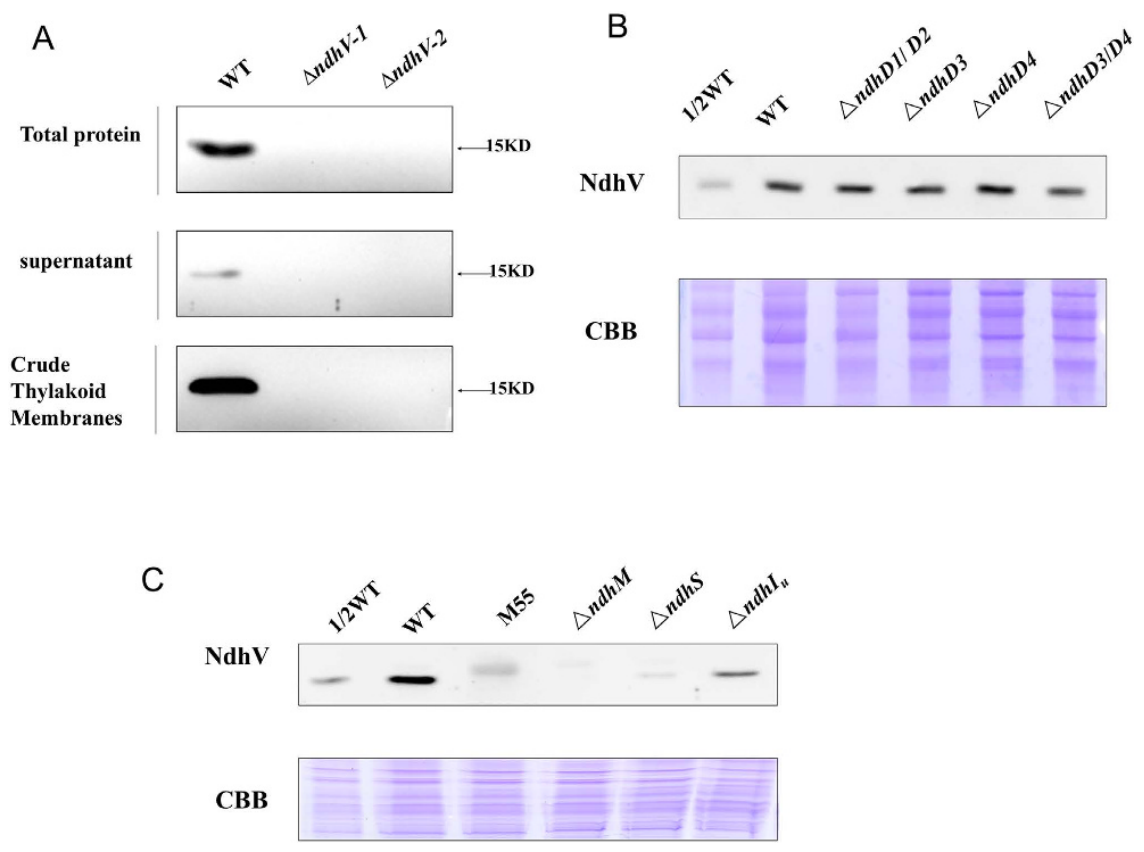

Figure 4. The location of NdhV in WT strain and the effects of mutation of Ndh subunits on NdhV. (A) Immunodetection of $\mathrm{NdhV}$ in the total proteins, supernatant and thylakoid membranes of WT and $\Delta n d h V$ strains. Total Proteins: The material obtained after broken by glass beads; supernatant, Crude Thylakoid Membranes: supernatant and precipitation after centrifugation of total proteins at $20,000 \times g$ for $30 \mathrm{~min}$ at $4^{\circ} \mathrm{C}$, respectively. (B) Immunodetection of $\mathrm{NdhV}$ in thylakoid membranes from WT (including indicated serial dilutions), $\Delta n d h D 1 / D 2, \Delta n d h D 3, \Delta n d h D 4$ and $\Delta n d h D 3 / D 4$ mutants. Immunoblotting was performed using antibodies against NdhV. Each Lane was loaded with $25 \mu \mathrm{g}$ total proteins. In the lower panel, a piece of replicated gel stained with Coomassie Brilliant Blue (CBB) was used as a loading control. (C) Immunodetection of NdhV in thylakoid membranes from WT (including indicated serial dilutions), M55, $\Delta n d h M, \Delta n d h S$, $\Delta n d h I_{U}$ (partly deletion of NdhI) mutants. Immunoblotting was performed using antibodies against NdhV. Each Lane was loaded with $25 \mu \mathrm{g}$ total proteins. In the lower panel, a piece of replicated gel stained with Coomassie Brilliant Blue (CBB) was used as a loading control.

high light in WT. The results suggest that the up-regulation of $\mathrm{NdhV}$ is required for regulation of $\mathrm{NDH}$ activity in response to high lights in cyanobacteria.

The capacity of photosynthesis was suppressed at the high light and low $\mathrm{pH}$ in $\Delta$ ndhV. To check whether NdhV functions in protecting the cyanobacterium against the high light stress, we compared the capacity of photosynthesis between WT and $\Delta n d h V$ in response to the high light, as reflected by photosynthetic $\mathrm{O}_{2}$ evolution at higher $\mathrm{pH}(8.0)$ where the $\mathrm{HCO}_{3}{ }^{-}$is predominant and lower $\mathrm{pH}(6.5)$ where $\mathrm{CO}_{2}$ is predominant. With the increase in the light intensity, the rate of photosynthetic $\mathrm{O}_{2}$ evolution increased, but there was not much difference between WT and $\Delta n d h V$ at pH 8.0 (Fig. 7A). However, the rate of photosynthetic $\mathrm{O}_{2}$ evolution in $\Delta n d h V$ was approximately $10 \%$ lower than that in $\mathrm{WT}$ at $\mathrm{pH} 6.5$ at higher light intensities (Fig. 7B). The results suggest that $\mathrm{NdhV}$ is also required for photosynthetic $\mathrm{CO}_{2}$ assimilation under the high light and low $\mathrm{pH}$ stressed conditions.

\section{Discussion}

It has been shown that mutation of $N d h V$ caused completely the loss of the NDH activity in Arabidopsis ${ }^{35}$ but only partly in cyanobacterium Synechocystis 6803 (Gao et al.) ${ }^{16}$, which is confirmed in our work (Fig. 1). The only partial suppression of the NDH-1 activity (Fig. 1C) by deletion of the cyanobacterial NdhV is probably attributed to the compensation of the activity from different types of NDH-1 in cyanobacteria ${ }^{7}$. On the other hand, similar with the chloroplast $\mathrm{NdhV}$, the cyanobacterial $\mathrm{NdhV}$ is also demonstrated to localize in the fragile part of NDH-1 and may interact with the electron donor domain of NDH-1 by the observation of the severe suppression of the accumulation of $\mathrm{NdhV}$ in $\Delta n d h S$ (Fig. 4C). In addition, the accumulation of NdhV was almost lost in the thylakoid membranes in M55 and in $\Delta N d h M$ (Fig. 4C) in which the hydrophilic subcomplex of NDH-1 complexes are degraded (He et al. $)^{20}$, but it was not affected either in $N d h D 3 / D 4$ defective mutant (Fig. 4B) in which only NDH-1L and NDH-1M exist, or in NdhD1/D2 defective mutant (Fig. 4B) in which NDH-1M, NDH-1MS' are still present. Moreover, NdhV co-localized with Ndh subunits of NDH-1MS', NDH-1L and NDH-1M complexes (Fig. 5A). Considering the cells were cultured under high $\mathrm{CO}_{2}$ culture condition, NDH-1MS would not be visible. Those results let us conclude that $\mathrm{NdhV}$ interacts with the electron donor domain of these complexes which contains NDH-1M as a skeleton ${ }^{30}$. Although defect in NdhS and other hydrophilic subunits affected the accumulation of $\mathrm{NdhV}$ (Fig. 4C), but deletion of $N d h V$ didn't affect the accumulation of relevant NDH-1 subunits 
A

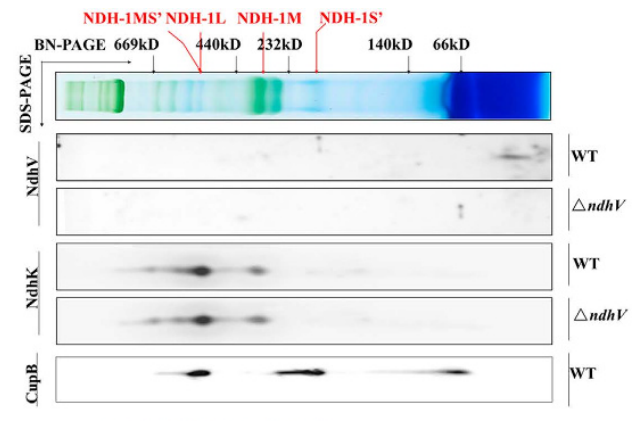

NDH-1MS' NDH-1L NDH-1M

B

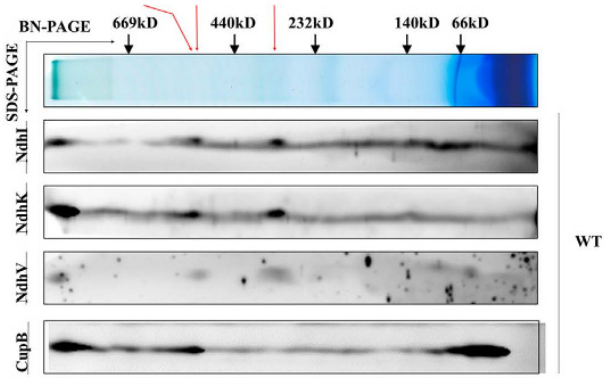

Figure 5. The location of NdhV in NDH-1 complexes in WT. (A) Thylakoid membrane proteins from WT and $\Delta n d h V$ strains were separated by the BN-PAGE and further subjected to a 2D/SDS-PAGE. The proteins were immunodetected with antibodies against $\mathrm{NdhK}$ and $\mathrm{NdhV}$. The positions of molecular mass markers in the BN-gel are indicated. (B) Thylakoid membrane proteins from WT strain were crosslinking by DSP, then separated by BN-PAGE and further subjected to 2D/SDS-PAGE. The proteins were immunodetected with antibodies against NdhI, NdhK, NdhV and CupB. The positions of molecular mass markers in the BN-gel are indicated.

A

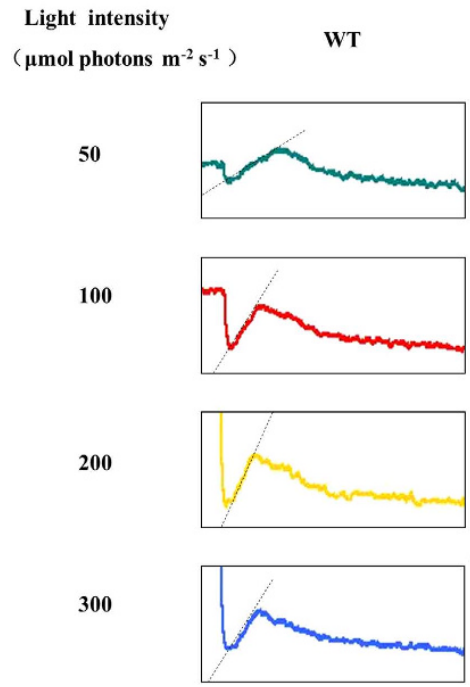

B

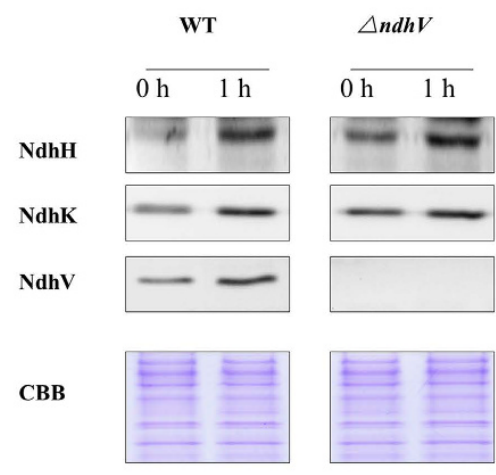

Figure 6. Monitoring of NDH-1 activity of WT and $\Delta n d h V$ strains under different light intensities. (A) Monitoring of NDH-1 activity of WT and $\Delta n d h V$ strains in different light intensities using chlorophyll fluorescence analysis. $\mathrm{OD}_{730}$ of the cells was about 0.3 . The cells were exposed to the different actinic light (shown in the figure) for $90 \mathrm{~s}$. Then the actinic light was turned off, and the transient increase in chlorophyll fluorescence level was ascribed to NDH activity. (B) Immunodetection of $\mathrm{NdhH}, \mathrm{K}, \mathrm{V}$ in total proteins of WT and $\Delta n d h V$ strains before and after treatment with high light. The cell was cultured to mid-logarithmic phase under normal light $(0 \mathrm{~h})$, then the cell cultures were transferred to high light $\left(\sim 200 \mu \mathrm{mol}\right.$ photons $\left.\mathrm{m}^{-2} \mathrm{~s}^{-1}\right)$ for 1 hour $(1 \mathrm{~h})$. Immunoblotting was performed using antibodies against $\mathrm{NdhH}$, NdhK and NdhV. Each lane was loaded with $25 \mu \mathrm{g}$ proteins. In the lower panel, a piece of replicated gel stained with Coomassie Brilliant Blue (CBB) was used as a loading control. 
A

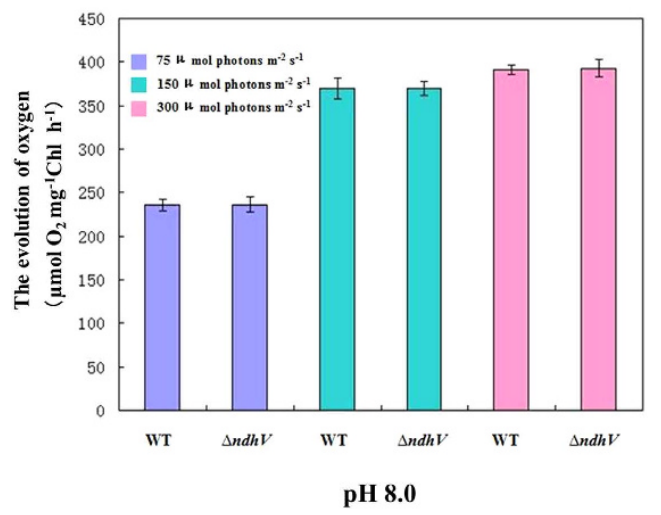

B

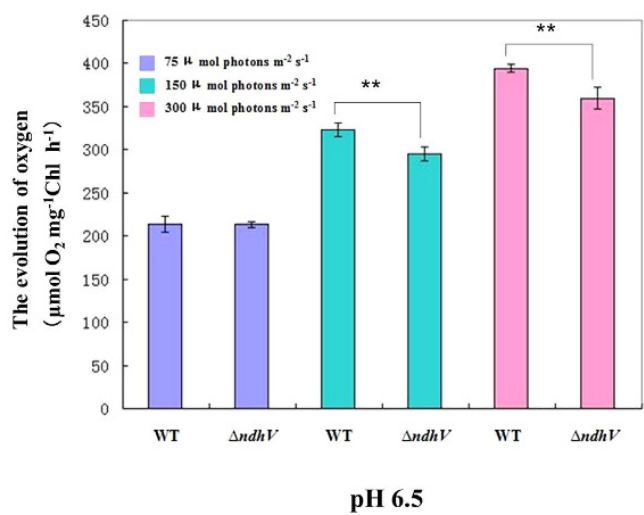

Figure 7. The evolution of oxygen in WT and $\Delta n d h V$ strains at different light intensities and different pHs. (A,B). The evolution of oxygen in WT and $\Delta n d h V$ strains under different light intensities at pH 8.0 (A) and 7.0 (B). WT and $\Delta n d h V$ strains were grown at $30^{\circ} \mathrm{C}$ in BG-11 medium buffered with $5 \mathrm{mM}$ Tris- $\mathrm{HCl}$ at $\mathrm{pH}$ 8.0 and 7.0, respectively, in $2 \% \mathrm{CO}_{2}\left(\mathrm{v} / \mathrm{v}\right.$ in air) at $50 \mu \mathrm{mol}$ photons $\mathrm{m}^{-2} \mathrm{~s}^{-1}$. Then the cells at logarithmic phase $\left(\mathrm{OD}_{730} \approx 0.5\right)$ were used to measure the evolution of oxygen in the presence of $200 \mu \mathrm{M} \mathrm{NaHCO} 3$ at the light intensities of 70, 150 and $300 \mu \mathrm{mol}$ photons $\mathrm{m}^{-2} \mathrm{~s}^{-1}$, respectively. Values are means $\pm \mathrm{SE}$ of five independent measurements. Asterisk indicates significant differences ( $\mathrm{t}$-test, $* \mathrm{P}<0.05$ and $* * \mathrm{P}<0.01$ ).

nor the assembly of NDH-1 complexes (Fig. 1S), implying that NdhV is a peripheral subunit functioning in regulation of NDH-1.

The growth phenotype of both wild type and $\Delta n d h V$ cultured in liquid medium bubbling with $2 \% \mathrm{CO}_{2}$ at $\mathrm{pH}$ 6.5 and low light was almost the same (Fig. 2E), which was consistent with the previous observation (Gao et al. $)^{16}$ who therefore concluded that NdhV didn't play any role in $\mathrm{CO}_{2}$ uptake. However, when $\Delta n d h V$ was cultured in agar plate in $2 \% \mathrm{CO}_{2}$ at $\mathrm{pH} 6.5$ and low light, the growth was slightly suppressed (Fig. $2 \mathrm{~B}$ ), suggesting that the bubbling may increase the diffusion of $\mathrm{HCO}_{3}{ }^{-}$into the carboxysome even if it was not predominant, but the ratio of $\mathrm{CO}_{2}$ to $\mathrm{HCO}_{3}{ }^{-}$to is still about 0.7 at $\mathrm{pH}$.5. In addition, the growth of $\Delta n d h V$ was evidently suppressed at high light when $\mathrm{HCO}_{3}{ }^{-}$or $\mathrm{CO}_{2}$ were limited at low $\mathrm{pH}$ or low $\mathrm{CO}_{2}$ (Fig. 2C,D,F) but not significantly at high light when the inorganic carbon is saturated at high $\mathrm{pH}$ or high $\mathrm{CO}_{2}$ (Fig. 2C,D). The results suggest that $\mathrm{NdhV}$ is required for the efficient $\mathrm{CO}_{2}$ uptake at high light especially under the conditions when the inorganic carbon is limited, which is further supported by the observation that the $\mathrm{CO}_{2}$ uptake activity was evidently suppressed at the high light of $300 \mu \mathrm{mol}$ photons $\mathrm{m}^{-2} \mathrm{~s}^{-1}$ under low $\mathrm{CO}_{2}$ but not under high $\mathrm{CO}_{2}$ condition (Fig. 2C) and also by the suppression of photosynthetic $\mathrm{O}_{2}$ evolution at the high light at low $\mathrm{pH}$ (Fig. 7B) but not at high pH (Fig. 7A). Defect in the cyanobacterial NdhV caused partially (about 10\%) suppression of the rate of $\mathrm{CO}_{2}$ uptake (Fig. 3A), it might be attributed to the partly contribution of $\mathrm{NdhV}$ to the cyclic electron or respiratory electron transports which might function in providing transthylakoid membrane proton gradient (Fig. 3C) for ATP synthesis or alkaline pocket (Kaplan and Reinhold, 1999).

The previous study showed that both the cyclic electron flow around PSI and respiratory $\mathrm{O}_{2}$ uptake mediated by NDH-1 was enhanced at high light $\left(100 \mu \mathrm{mol}\right.$ photons $\left.\mathrm{m}^{-2} \mathrm{~s}^{-1}\right)$, accordingly the photosynthetic $\mathrm{O}_{2}$ evolution was also up-regulated ${ }^{34}$, suggesting that the up-regulation of $\mathrm{NDH}-1$ is required for high activity of photosynthesis. The up-regulation of the NDH-1 activity induced by the high lights was suppressed when NdhV is deleted (Fig. 6A), suggesting that the cyanobacterial NdhV is involved in the regulation of NDH-1 activity in response to the high lights. The significant up-regulation of $\mathrm{NdhV}$ by the treatment of the high light in the wild type (Fig. 6B) implies its important role in the regulation of photosynthesis, as one of components related with the electron donor domain of NDH-1. The evident suppression of the rate of $\mathrm{CO}_{2}$ uptake at the high light $(100 \mu$ mol photons $\mathrm{m}^{-2} \mathrm{~s}^{-1}$ ) either at high $\mathrm{CO}_{2}$ or low $\mathrm{CO}_{2}$ (Fig. 3A) further supports this mention. In addition, the suppression of the photosynthetic oxygen evolution (Fig. 7B) and the growth (Fig. 2D,F) at the high light when $\mathrm{CO}_{2}$ was limited in the NdhV deleted mutant might be attributed to the loss of the up-regulation for NDH-1 activity under the stressed conditions (Fig. 6A). It has been indicated that cyclic electron flow around PSI plays an important role in providing ATP for carbon assimilation ${ }^{42,43}$. Actually, the enhancement of cyclic electron flow around PS I by treatment with low concentration of $\mathrm{NaHSO}_{3}$ enables cyanobacteria to generate sufficient proton gradient across the thylakoid membrane, thereby increased the biomass of Synechocystis PCC $6803^{44}$. Therefore, in NdhV deleted mutant, the partial suppression of NDH-1 activity (Fig. 1C) would lower the building-up of proton gradient across thylakoid membranes (Fig. 3C), resulting in the decrease in the activity of $\mathrm{CO}_{2}$ uptake (Fig. 3) and suppressed growth, especially when $\mathrm{HCO}_{3}{ }^{-}$and $\mathrm{CO}_{2}$ were limited under high light conditions (Fig. 2D).

In conclusion, our work demonstrate that the cyanobacterial $\mathrm{NdhV}$ subunit locates at the hydrophilic parts of $\mathrm{NDH}-1 \mathrm{M}$ and plays an essential role in regulation of NDH-1 activity for efficient operation of cyclic electron flow around PS I and $\mathrm{CO}_{2}$ uptake especially at high light. 


\begin{abstract}
Materials and Methods
Cell culture conditions. The Synechocystis 6803 wild type and mutant cells were cultured in BG-11 medium ${ }^{45}$ buffered with Tris- $\mathrm{HCl}(5 \mathrm{mM}, \mathrm{pH} 8.0)$ at $30^{\circ} \mathrm{C}$ under $50 \mu \mathrm{mol}$ photons $\mathrm{m}^{-2} \mathrm{~s}^{-1}$. The cells were bubbled with $2 \% \mathrm{v} / \mathrm{v} \mathrm{CO}_{2}$ in air. The BG-11 solid medium used was BG-11 supplemented with $1.5 \%$ agar, Tris- $\mathrm{HCl}$ ( $10 \mathrm{mM}, \mathrm{pH} 8.0$ ), and $0.3 \% \mathrm{Na}_{2} \mathrm{~S}_{2} \mathrm{O}_{3}$. The illumination was provided by fluorescence lamps at $50 \mu$ mol photons $\mathrm{m}^{-2} \mathrm{~s}^{-1}$. According to culturing requirements of wild type and mutant cells, the BG-11 medium was buffered with $10 \mathrm{mM}$ TES-KOH at several other $\mathrm{pH}$ conditions.
\end{abstract}

Construction of $\Delta \boldsymbol{n d h V}$ mutant. The upstream and downstream regions of $\operatorname{sll0272}(\mathrm{NdhV})$ and a DNA fragment encoding a kanamycin resistance $\left(\operatorname{Kan}^{\mathrm{R}}\right)$ cassette were firstly amplified by PCR using specific oligonucleotide primers (Table S1). Then the PCR products of upstream of sllo272 and Kanamycin resistance $\left(\right.$ Kan $\left.^{R}\right)$ cassette were used as templates to obtain the second PCR products(SP1), and the PCR products of downstream of $s l l 0272$ and $\mathrm{Kan}^{R}$ cassette were used as templates to obtain the second PCR products(SP2). The third round PCR product containing the upstream and downstream regions inserted by a $\mathrm{Kan}^{R}$ cassette were amplified by PCR using SP1 and SP2 as templates. Then the final products were ligated to the pMD19T (Fig. 1A), to make the construct for transforming the WT cells of Synechocystis 6803 as described by Williams and Szalay ${ }^{46}$. The transformants were spread on agar plates containing BG-11 medium and Kanamycin $\left(10 \mu \mathrm{g} . \mathrm{ml}^{-1}\right)$ buffered at $\mathrm{pH} 8.0$, the BG-11 solid medium plates were incubated in $2 \% \mathrm{v} / \mathrm{v} \mathrm{CO}_{2}$ in air. The mutated $\mathrm{NdhV}$ in the transformants was segregated to homogeneity as determined by PCR amplification and immunoblotting.

The measurement of chlorophyll fluorescence. The transient increase in chlorophyll fluorescence after actinic light had been turned off was monitored by means of using a PAM Chl fluorometer (Walz, Effeltrich, Germany), emitter-detector-cuvette assembly (ED-101US) and unit 101ED as previously described ${ }^{37,38}$.

Oxygen exchange. The evolution of oxygen under different light intensities were determined in cultural BG-11 medium that contained the mid-logarithmic cell of Synechocystis 6803 at about $2.5 \mu \mathrm{g}$ chlorophyll ml ${ }^{-1}$ with a Clark-type oxygen electron. The whole monitoring process was performed at $30^{\circ} \mathrm{C}$.

$\mathrm{CO}_{2}$ uptake measurement. $\mathrm{CO}_{2}$ uptake was measured with a portable open-flow gas exchange system Li-6400 (LI-COR Biosciences). Air temperature of the leaf chamber was maintained at $30^{\circ} \mathrm{C}$, the photosynthetically active radiation (PAR) was 100 or $300 \mu \mathrm{mol}$ photons $\mathrm{m}^{-2} \mathrm{~s}^{-1}$ and the flow rate of the air in the measuring chamber was $50 \mu \mathrm{mol} \mathrm{s}^{-1}$. $\mathrm{CO}_{2}$ concentration was controlled at $2 \%$ (v/v in air) or $0.04 \%$. The cells of WT and $\Delta n d h V$ strains grown at $30^{\circ} \mathrm{C}$ in BG-11 medium at $2 \% \mathrm{CO}_{2}$ were collected at mid-logarithmic stage by centrifugation and re-suspended in fresh BG-11 medium. They were concentrated into 100 of $\mathrm{OD}_{730}$, and $30 \mu \mathrm{l}$ of each cell suspension was placed on the agar plate as a spot incubated in the growth chamber before $\mathrm{CO}_{2}$ uptake measurement. Each cell spot on agar was cut out into a square of $1 \mathrm{~cm} \times 1 \mathrm{~cm}$ and put on a cover glass to measure the $\mathrm{CO}_{2}$ uptake rate. Same size of agar was used as control. Measurements were repeated three times and the averages were recorded.

Isolation of crude thylakoid membranes. Synechocystis 6803 thylakoid membranes were isolated as described by Gombos et al. ${ }^{47}$ with some modifications as follows. The cell cultures (1L) were centrifuged at the logarithmic phase and then resuspended in $20 \mathrm{ml}$ disruption buffer [ $10 \mathrm{mM}$ HEPES-NaOH, $5 \mathrm{mM}$ sodium phosphate, $\mathrm{pH} 7.5,10 \mathrm{mM} \mathrm{MgCl}_{2}, 10 \mathrm{mM} \mathrm{NaCl}$, and $20 \% \mathrm{v} / \mathrm{v}$ glycerol)], broken by vortexing with glass beads $(150-212 \mu \mathrm{m})$ for three times at $70 \mathrm{~Hz}$ for $30 \mathrm{~s}$ with $30 \mathrm{~s}$ interval cooling using a Tissuelyser- 48 system (Shanghi Jingxin). And then the lysis was centrifuged at $5000 \mathrm{~g}$ for $5 \mathrm{~min}$ at $4^{\circ} \mathrm{C}$ to remove glass beads and unbroken cells. The crude thylakoid membranes and supernatant were obtained by centrifugation of the homogenate at $20000 \mathrm{~g}$ for $30 \mathrm{~min}$ at $4{ }^{\circ} \mathrm{C}$ from the precipitation and supernatant, respectively. The membranes were washed with buffer $\mathrm{B}[330 \mathrm{mM}$ sorbitol, $50 \mathrm{mM}$ Bis-Tris-HCl, pH 7.0, 0.5 mM PMSF (Sigma, MO)] and re-suspended in buffer C [25 mM BisTris- $\mathrm{HCl}, \mathrm{pH}$ 7.0, $10 \mathrm{mM} \mathrm{MgCl}_{2}, 20 \%$ v/v glycerol, 0.1 units RNase-free DNase RQ1 (Promega, Madison, WI), $0.5 \mathrm{mM} \mathrm{PMSF].}$

Cross-linking of the thylakoid membranes. The cross-linking assay was performed as described previously $^{48}$. Thylakoid membranes were resuspended in $1 \mathrm{ml}$ of $20 \mathrm{mM}$ Hepes- $\mathrm{KOH}, \mathrm{pH} 8.0,5 \mathrm{mM} \mathrm{MgCl}_{2}(0.5 \mathrm{mg}$ chlorophyllml ${ }^{-1}$ ) and incubated with $2.5 \mathrm{mM}$ DSP (Dithiobis[succinimidyl propionate]) for $30 \mathrm{~min}$ at room temperature in the dark. After cross-linking, reactions were quenched with addition of $60 \mathrm{mM}$ Tris- $\mathrm{HCl}, \mathrm{pH} 7.5$ for $15 \mathrm{~min}$. Thylakoids were pelleted after centrifuged again at $20000 \mathrm{~g}$ for $30 \mathrm{~min}$ at $4{ }^{\circ} \mathrm{C}$ and solubilized at $0.5 \mathrm{mg}$ of chlorophyll $\mathrm{ml}^{-1}$ in a buffer containing $20 \mathrm{mM}$ Hepes-KOH, pH 8.0, $200 \mathrm{mM} \mathrm{NaCl}, 1.2 \%$ Triton X-100, $1 \mathrm{mM}$ PMSF for $30 \mathrm{~min}$ on ice. Insoluble thylakoids were removed by centrifugation at $22000 \mathrm{~g}$ for $10 \mathrm{~min}$ at $4{ }^{\circ} \mathrm{C}$ and the supernatant was transferred to new tubes for further analysis.

Electrophoresis and immunoblotting. BN-PAGE of Synechocystis 6803 membranes was performed as described previously ${ }^{48}$ with slight modifications. The chlorophyll a concentration of the membranes solubilized in buffer $\mathrm{C}$ was diluted at $0.5 \mathrm{mg} \mathrm{ml}^{-1}$, then the $1 / 20$ vloume of $20 \% n$-dodecyl- $\beta$-D-maltoside (DM) was added. After incubation on ice for $20 \mathrm{~min}$ and centrifugation at $20000 \times g$ for another $15 \mathrm{~min}$, the supernatants were supplemented with 1/10 volume of BN sample buffer ( $5 \%$ Serva Blue G, $100 \mathrm{mM}$ BisTris- $\mathrm{HCl}, \mathrm{pH}$ $7.0,30 \% \mathrm{w} / \mathrm{v}$ sucrose, $500 \mathrm{mM} \varepsilon$-amino- $n$-caproic acid and $10 \mathrm{mM}$ EDTA). Solubilized membranes were then applied to a $1.0 \mathrm{~mm}$ thick $5-13 \%$ acrylamide gradient gel. Samples of $5 \mu \mathrm{g}$ chlorophyll $a$ were loaded on the gel. Electrophoresis was performed at $4{ }^{\circ} \mathrm{C}$ by increasing the voltage gradually from $50-200 \mathrm{~V}$ during the $5 \mathrm{~h}$ run. For electrophoresis in the second dimension, the lanes of the BN gel were cut out and incubated in $1 \times$ SDS sample loading buffer containing $2 \% \beta$-mercaptoethanol for $30 \mathrm{~min}$. SDS-PAGE of the lanes of the BN gel was performed on a $15 \%$ polyacrylamide gel as described previously ${ }^{49}$. 
For immunoblotting, the proteins were electrotransferred to a polyvinylidene difluoride (PVDF) membrane (Immobilon-P; Millipore) and detected using protein-specific antibodies with the ECL assay kit (BioRad) according to the manufacturer's protocol. Antibody against the NdhV protein of Synechocystis 6803 was raised in our laboratory. To amplify the $N d h V$ gene, primer sequences were listed in Table S1. The PCR product was ligated into vector pET51b (Novagen). The plasmid was used to transform E.coli strain BL21 (DE3) pLysS for expression. Polyclonal antibody was raised in a rabbit from purified recombinant protein. The antibodies against CupB, $\mathrm{NdhH}, \mathrm{NdhI}, \mathrm{NdhK}$, and NdhM were previously raised in our laboratory.

Quinacrine (QA) fluorescence quenching. Fluorescence of Quinacrine (QA) at $503 \mathrm{~nm}$ using the PAM chlorophyll fluorometer (Maxi-version, Walz, Effeltrich, Germany) attached with a US-370 emitter with an emission peak at $375 \mathrm{~nm}$ and a PM-101/D detector as described previously ${ }^{50}$. Cells were harvested at logarithmic phase and suspended in reaction mixture contained $5 \mathrm{mM}$ Tris/MES ( $\mathrm{pH} 8.0$ ), 0.3 M mannitol, $2 \mathrm{mM}$ DTT, $5 \mathrm{mM}$ D-Glucose, $1.5 \mu \mathrm{M}$ ATP, $2.5 \mu \mathrm{M}$ QA with a final chlorophyll concentration of $150 \mu \mathrm{g} / \mathrm{ml}$. The quenching of QA fluorescence was induced by adding the cells sample to $2 \mathrm{ml}$ reaction mixture after the background fluorescence became stable about 2 min after started the measurement.

\section{References}

1. Mi, H. L., Endo, T., Schreiber, U., Ogawa, T. \& Asada, K. Electron donation from cyclic and respiratory flows to the photosynthetic intersystem chain is mediated by pyridine-nucleotide dehydrogenase in the cyanobacterium synechocystis PCC-6803. Plant and Cell Physiology 33, 1233-1237 (1992).

2. Ogawa, T. A gene homologous to the subunit-2 gene of nadh dehydrogenase is essential to inorganic carbon transport of synechocystis PCC6803. Proceedings of the National Academy of Sciences of the United States of America 88, 4275-4279, doi: 10.1073/ pnas.88.10.4275 (1991).

3. Ifuku, K., Endo, T., Shikanai, T. \& Aro, E.-M. Structure of the Chloroplast NADH Dehydrogenase-Like Complex: Nomenclature for Nuclear-Encoded Subunits. Plant and Cell Physiology 52, 1560-1568, doi: 10.1093/pcp/pcr098 (2011).

4. Ishikawa, N., Endo, T. \& Sato, F. Electron transport activities of Arabidopsis thaliana mutants with impaired chloroplastic NAD(P) H dehydrogenase. Journal of Plant Research 121, 521-526, doi: 10.1007/s10265-008-0180-x (2008).

5. Peng, L., Fukao, Y., Fujiwara, M., Takami, T. \& Shikanai, T. Efficient Operation of NAD(P)H Dehydrogenase Requires Supercomplex Formation with Photosystem I via Minor LHCI in Arabidopsis. Plant Cell 21, 3623-3640, doi: 10.1105/tpc.109.068791 (2009).

6. Friedrich, T. \& Scheide, D. The respiratory complex I of bacteria, archaea and eukarya and its module common with membranebound multisubunit hydrogenases. Febs Letters 479, 1-5, doi: 10.1016/s0014-5793(00)01867-6 (2000).

7. Herranen, M. et al. Towards functional proteomics of membrane protein complexes in Synechocystis sp PCC 6803. Plant Physiology 134, 470-481, doi: 10.1104/pp.103.032326 (2004).

8. Zhang, S. S. \& Grosse, F. Multiple functions of nuclear DNA helicase II (RNA helicase A) in nucleic acid metabolism. Acta Biochimica Et Biophysica Sinica 36, 177-183 (2004).

9. Baradaran, R., Berrisford, J. M., Minhas, G. S. \& Sazanov, L. A. Crystal structure of the entire respiratory complex I. Nature 494, 443-448, doi: 10.1038/nature11871 (2013).

10. Birungi, M. et al. Possibilities of subunit localization with fluorescent protein tags and electron microscopy examplified by a cyanobacterial NDH-1 study. Biochim. Biophys. Acta-Bioenerg. 1797, 1681-1686, doi: 10.1016/j.bbabio.2010.06.004 (2010).

11. Prommeenate, P., Lennon, A. M., Markert, C., Hippler, M. \& Nixon, P. J. Subunit composition of NDH-1 complexes of Synechocystis sp PCC 6803 - Identification of two new ndh gene products with nuclear-encoded homologues in the chloroplast Ndh complex. Journal of Biological Chemistry 279, 28165-28173, doi: 10.1074/jbc.M401107200 (2004).

12. Battchikova, N., Zhang, P. P., Rudd, S., Ogawa, T. \& Aro, E. M. Identification of NdhL and Ssl1690 (NdhO) in NDH-1L, and NDH$1 \mathrm{M}$ complexes of Synechocystis sp PCC 6803. Journal of Biological Chemistry 280, 2587-2595, doi: 10.1074/jbc.M410914200 (2005).

13. Nowaczyk, M. M. et al. NdhP and NdhQ: Two Novel Small Subunits of the Cyanobacterial NDH-1 Complex. Biochemistry 50, 1121-1124, doi: 10.1021/bi102044b (2011).

14. Schwarz, D., Schubert, H., Georg, J., Hess, W. R. \& Hagemann, M. The Gene sml0013 of Synechocystis Species Strain PCC 6803 Encodes for a Novel Subunit of the NAD(P)H Oxidoreductase or Complex I That Is Ubiquitously Distributed among Cyanobacteria. Plant Physiology 163, 1191-1202, doi: 10.1104/pp.113.224287 (2013).

15. Zhang, J. et al. NdhP Is an Exclusive Subunit of Large Complex of NADPH Dehydrogenase Essential to Stabilize the Complex in Synechocystis sp Strain PCC 6803. Journal of Biological Chemistry 289, 18770-18781, doi: 10.1074/jbc.M114.553404 (2014).

16. Zhao, J., Rong, W., Gao, F., Ogawa, T. \& Ma, W. Subunit Q Is Required to Stabilize the Large Complex of NADPH Dehydrogenase in Synechocystis sp Strain PCC 6803. Plant Physiology 168, 443-+, doi: 10.1104/pp.15.00503 (2015).

17. Yamamoto, H., Peng, L., Fukao, Y. \& Shikanai, T. An Src Homology 3 Domain-Like Fold Protein Forms a Ferredoxin Binding Site for the Chloroplast NADH Dehydrogenase-Like Complex in Arabidopsis. Plant Cell 23, 1480-1493, doi: 10.1105/tpc.110.080291 (2011).

18. Battchikova, N. et al. Identification of novel Ssl0352 protein (NdhS), essential for efficient operation of cyclic electron transport around photosystem I, in NADPH: plastoquinone oxidoreductase (NDH-1) complexes of Synechocystis sp. PCC 6803. (vol 286, pg 36992, 2011). Journal of Biological Chemistry 287, 8660-8660, doi: 10.1074/jbc.A111.263780 (2012).

19. Yamamoto, H. \& Shikanai, T. In Planta Mutagenesis of Src Homology 3 Domain-like Fold of NdhS, a Ferredoxin-binding Subunit of the Chloroplast NADH Dehydrogenase-like Complex in Arabidopsis A CONSERVED ARG-193 PLAYS A CRITICAL ROLE IN FERREDOXIN BINDING. Journal of Biological Chemistry 288, 36328-36337, doi: 10.1074/jbc.M113.511584 (2013).

20. He, Z. et al. NDH-1L interacts with ferredoxin via the subunit NdhS in Thermosynechococcus elongatus. Photosynthesis Research 126, 341-349, doi: 10.1007/s11120-015-0090-4 (2015).

21. Volokita, M., Zenvirth, D., Kaplan, A. \& Reinhold, L. Nature of the inorganic carbon species actively taken up by the cyanobacterium anabaena-variabilis. Plant Physiology 76, 599-602, doi: 10.1104/pp.76.3.599 (1984).

22. Lyman, F. E. Environmental-factors affecting distribution of mayfly nymphs in douglas lake, michigan. Ecology 37, 568-576, doi: 10.2307/1930181 (1956).

23. Kaplan, A. \& Reinhold, L. $\mathrm{CO}_{2}$ concentrating mechanisms in photosynthetic microorganisms. Annual Review of Plant Physiology and Plant Molecular Biology 50, 539- + , doi: 10.1146/annurev.arplant.50.1.539 (1999).

24. Ogawa, T. \& Kaplan, A. Inorganic carbon acquisition systems in cyanobacteria. Photosynthesis Research 77, 105-115, doi: 10.1023/a:1025865500026 (2003).

25. Ogawa, T. \& Mi, H. Cyanobacterial NADPH dehydrogenase complexes. Photosynthesis Research 93, 69-77, doi: 10.1007/s11120006-9128-y (2007).

26. Price, G. D. et al. The cyanobacterial CCM as a source of genes for improving photosynthetic CO2 fixation in crop species. Journal of experimental botany 64, 753-768, doi: 10.1093/Jxb/Ers257 (2013).

27. Ohkawa, H., Price, G. D., Badger, M. R. \& Ogawa, T. Mutation of ndh genes leads to inhibition of CO2 uptake rather than HCO3uptake in Synechocystis sp strain PCC 6803. Journal of Bacteriology 182, 2591-2596, doi: 10.1128/jb.182.9.2591-2596.2000 (2000). 
28. Shibata, M. et al. Distinct constitutive and low-CO2-induced CO2 uptake systems in cyanobacteria: Genes involved and their phylogenetic relationship with homologous genes in other organisms. Proceedings of the National Academy of Sciences of the United States of America 98, 11789-11794, doi: 10.1073/pnas.191258298 (2001).

29. Maeda, S., Badger, M. R. \& Price, G. D. Novel gene products associated with NdhD3/D4-containing NDH-1 complexes are involved in photosynthetic CO2 hydration in the cyanobacterium, Synechococcus sp PCC7942. Molecular Microbiology 43, 425-435, doi: 10.1046/j.1365-2958.2002.02753.x (2002).

30. Zhang, P. P. et al. Expression and functional roles of the two distinct NDH-1 complexes and the carbon acquisition complex NdhD3/ NdhF3/CupA/Sll1735 in Synechocystis sp PCC 6803. Plant Cell 16, 3326-3340 (2004).

31. Zhang, P. P. et al. Isolation, subunit composition and interaction of the NDH-1 complexes from Thermosynechococcus elongatus BP-1. Biochemical Journal 390, 513-520, doi: 10.1042/bj20050390 (2005).

32. Xu, M., Ogawa, T., Pakrasi, H. B. \& Mi, H. Identification and localization of the CupB protein involved in constitutive $\mathrm{CO}(2)$ uptake in the cyanobacterium, Synechocystis sp strain PCC 6803. Plant and Cell Physiology 49, 994-997, doi: 10.1093/pcp/pcn074 (2008).

33. Deng, Y., Ye, J. Y., Mi, H. L. \& Shen, Y. K. Response of NAD(P)H dehydrogenase complex to the alteration of CO2 concentration in the cyanobacterium Synechocystis PCC6803. Journal of Plant Physiology 160, 967-970, doi: 10.1078/0176-1617-01053 (2003).

34. Mi, H. L., Deng, Y., Tanaka, Y., Hibino, T. \& Takabe, T. Photo-induction of an NADPH dehydrogenase which functions as a mediator of electron transport to the intersystem chain in the cyanobacterium Synechocystis PCC6803. Photosynthesis Research 70, 167-173, doi: 10.1023/a:1017946524199 (2001).

35. Fan, X., Zhang, J., Li, W. \& Peng, L. The NdhV subunit is required to stabilize the chloroplast NADH dehydrogenase-like complex in Arabidopsis. Plant Journal 82, 221-231, doi: 10.1111/tpj.12807 (2015).

36. Gao, F. et al. NdhV Is a Subunit of NADPH Dehydrogenase Essential for Cyclic Electron Transport in Synechocystis sp Strain PCC 6803. Plant Physiology 170, 752-760 (2016).

37. Mi, H. L., Endo, T., Ogawa, T. \& Asada, K. Thylakoid membrane-bound, nadph-specific pyridine-nucleotide dehydrogenase complex mediates cyclic electron-transport in the cyanobacterium synechocystis SP PCC-68038. Plant and Cell Physiology 36, 661-668 (1995)

38. Deng, Y., Ye, J. Y. \& Mi, H. L. Effects of low $\mathrm{CO} 2$ on NAD(P)H dehydrogenase, a mediator of cyclic electron transport around photosystem I in the cyanobacterium Synechocystis PCC6803. Plant and Cell Physiology 44, 534-540, doi: 10.1093/pcp/pcg067 (2003).

39. Shikanai, T. et al. Directed disruption of the tobacco ndhB gene impairs cyclic electron flow around photosystem I. Proceedings of the National Academy of Sciences of the United States of America 95, 9705-9709, doi: 10.1073/pnas.95.16.9705 (1998).

40. Teuber, M., Rogner, M. \& Berry, S. Fluorescent probes for non-invasive bioenergetic studies of whole cyanobacterial cells. Biochimica Et Biophysica Acta-Bioenergetics 1506, 31-46, doi: 10.1016/s0005-2728(01)00178-5 (2001).

41. Zhihui He, M. X., Yaozong Wu, Jing Lv. \& Pengcheng Fu, Hualing Mi. NdhM is required for the stability and the function of NAD(P) $\mathrm{H}$ dehydrogenase complexes involved in $\mathrm{CO}_{2}$ uptake in Synechocystis sp. strain PCC 6803 Journal of Biological Chemistry (2016).

42. Schurman.P, Buchanan, B. B. \& Arnon, D. I. Role of cyclic photophosphorylation in photosynthetic carbon-dioxide assimilation by isolated chloroplasts. Biochimica Et Biophysica Acta 267, 111-\&, doi: 10.1016/0005-2728(72)90143-0 (1972).

43. Slovacek, R. E. \& Hind, G. Correlation between photosynthesis and the transthylakoid proton gradient. Biochimica Et Biophysica Acta 635, 393-404, doi: 10.1016/0005-2728(81)90037-2 (1981).

44. Wang, H.-W., Mi, H., Ye, J.-Y., Deng, Y. \& Shen, Y.-K. Low concentrations of $\mathrm{NaHSO}_{3}$ increase cyclic photophosphorylation and photosynthesis in cyanobacterium Synechocystis PCC6803. Photosynthesis Research 75, 151-159 (2003).

45. Allen, M. M. Simple conditions for growth of unicellular blue-green algae on plates. J Phycol 4, 1-4 (1968).

46. Williams, J. G. K. \& Szalay, A. A. Stable integration of foreign DNA into the chromosome of the cyanobacterium Synechococcus R2. Gene 24, 37-51, doi: http://dx.doi.org/10.1016/0378-1119(83)90129-4 (1983).

47. Gombos, Z., Wada, H. \& Murata, N. The recovery of photosynthesis from low-temperature photoinhibition is accelerated by the unsaturation of membrane lipids: a mechanism of chilling tolerance. Proc. Natl. Acad. Sci. USA 91, 8787-8791 (1994).

48. Kügler, M., Jänsch, L., Kruft, V., Schmitz, U. \& Braun, H. P. Analysis of the chloroplast protein complexes by blue-native polyacrylamide gel electrophoresis (BN-PAGE). Photosynth Res 53, 35-44, doi: 10.1023/a:1005882406718 (1997).

49. Laemmli, U. K. Cleavage of structural proteins during the assembly of the head of bacteriophage T4. Nature 227, 680-685 (1970).

50. Xu, M., Shi, N., Li, Q. \& Mi, H. An active supercomplex of NADPH dehydrogenase mediated cyclic electron flow around Photosystem I from the panicle chloroplast of Oryza sativa. Acta biochimica et biophysica Sinica 46, 757-765, doi: 10.1093/abbs/ gmu064 (2014)

\section{Acknowledgements}

We thank retired Prof. Ogawa T in Nagoya University, Japan for providing M55, $\Delta n d h D 1 / D 2, \Delta n d h D 3 / D 4$ strains. This work was supported by grants from the State Key Basic Research and Development Plan 973 (No. 2013CB127005, 2015CB150104), the National Natural Scientific Foundation of China (No. 31270286, 31470338) and Shanghai Science Foundation (grant number 13DJ1400102).

\section{Author Contributions}

X.C. carried out the main research work and wrote part of the manuscript. Z.H. constructed NdhM, NdhS and NdhI deleted mutants; M.X. revised the manuscript; L.P. and H.M. desgined the researh and wrote part of the manuscript. All authors reviewed the manuscript.

\section{Additional Information}

Supplementary information accompanies this paper at http://www.nature.com/srep

Competing financial interests: The authors declare no competing financial interests.

How to cite this article: Chen, X. et al. NdhV subunit regulates the activity of type-1 NAD(P)H dehydrogenase under high light conditions in cyanobacterium Synechocystis sp. PCC 6803. Sci. Rep. 6, 28361; doi: 10.1038/ srep28361 (2016).

This work is licensed under a Creative Commons Attribution 4.0 International License. The images or other third party material in this article are included in the article's Creative Commons license, unless indicated otherwise in the credit line; if the material is not included under the Creative Commons license, users will need to obtain permission from the license holder to reproduce the material. To view a copy of this license, visit http://creativecommons.org/licenses/by/4.0/ 